\title{
The Challenge of Defining Equity and Adequacy in State School Finance Systems: A LOOK AT New York's ExPERIENCE
}

\section{By Vidhya Ananthakrishnan}

Abstract: The substantial reliance on local property tax revenues to finance school systems has led to significant funding disparities between property-rich and property-poor school districts. The recognition of these disparities has spawned decades of litigation in states whose constitutions guarantee a high-quality education. Legislators and judges are often asked to reconcile very different definitions of equity and adequacy, which are the concepts that underpin a high-quality, state-provided education, and are often confounded by attempts to achieve equity and adequacy on a state-wide basis, given the differences in property tax revenues. This article describes the complexities inherent in the concepts of equity and adequacy and examines a long-running attempt to reform New York's school financing methods to ensure that all school districts in the state have an equitable and adequate level of resources.

"In these days, it is doubtful that any child may reasonably be expected to succeed in life if he is denied the opportunity of an education.

Such an opportunity, where the state has undertaken to provide it, is a right which must be made available to all on equal terms."

-Chief Justice Earl Warren, from Brown v. Board of Education, 347 U.S. 483, 493 (1954)

\section{INTRODUCTION}

Spending on elementary and secondary education in the United States has grown at record levels over the past five decades, totaling almost $\$ 500$ billion in

Vidhya Ananthakrishnan is a 2005 graduate of the Master of Public Policy program at The George Washington University with a dual concentration in Public Finance/Budgeting and Social Policy. She received her B.A. degree in economics and international studies from Northwestern University in 2000. Vidhya currently works part-time at The Finance Project where she provides program assistance to the Children and Families group. Prior to moving to Washington, $D C$, she worked as a staff associate for the Neighborhood Family Services Coalition, a New York City-based advocacy organization focused on children and youth issues. combined federal, state, and local money each year (Olson 2005). But despite high hopes that a tremendous influx of public funds would suffice to ensure "equal", "adequate", or "thorough" systems of $\mathrm{K}-12$ education, large disparities in both resources and opportunities provided to students still persist among states and across school districts within states. Such circumstances have prompted education advocates to seek judicial interventions at both the federal and state levels to remedy these inequities.

New York's experience with school finance reform mirrors much of what has been happening nationwide. Specifically, problems with how the state distributes funds under its school aid formula have spawned a decade-long legal battle over the cost of an adequate education. This case, Campaign for Fiscal Equity, Inc. (CFE) v. the State of New York, culminated with a ruling in 2003 by the New York State Court of Appeals declaring that the state had grossly under-funded New York City's schools and thereby failed in its constitutional obligation to provide all children with a "sound, basic education." While the court's decision only required the state to provide more resources for New York City schools, many stakeholders and policymakers hope to use this opportunity to overhaul the entire state's school finance system.

In order to better understand the situation in New York, this article describes the evolution of the national school finance reform movement by describing traditional state school finance systems and discussing 
two of the major concepts associated with the reform efforts: equity and adequacy. Then the article turns to the current school financing system used in New York, highlighting some of the major inequities and inadequacies inherent in that system. Finally, the article will provide recommendations on how New York could ensure that future efforts to redesign the state's school financing system meet both equity and adequacy objectives.

\section{Traditional Structures of School Finance}

In most states, local property tax dollars are the primary source of revenue used to fund K-12 schools, constituting about 43 percent of all education spending (Yinger 2004). Unfortunately, because the property tax base is not distributed equally across school districts, some districts have a significantly larger property tax base per pupil than others, resulting in unequal perpupil funding across districts (Odden 1992). Thus, "property-rich" districts can raise substantially more money per pupil than "property-poor" districts, which in turn leads to large differences in spending among districts in the same state. These spending gaps are further exacerbated by the fact that higher concentrations of students who are relatively more costly to educate (e.g., children who are "economically disadvantaged" or have limited English proficiency) generally reside in "property-poor" districts rather than in "property-rich" districts (Yinger 2004).

In an effort to equalize differences in local fiscal capacity, most states have instituted a "minimum foundation program" (Odden and Picus 2000). When the foundation program approach was first introduced in the 1920s, it had two major components:

1) set a base level of financial support for all schools, financed by state and local revenues; and

2) supplement these funds with an amount determined by the state meant to make up for the unequal size of a district's property tax base per pupil (Odden and Picus 2000).
Unfortunately, most state foundation programs have proven woefully inadequate, in part because their funding levels are determined by politics instead of by a "genuine statewide appraisal of what is actually necessary to fund an 'adequate' education" (Guthrie and Rothstein 1999, 214). As a result, these programs are not only contingent on the amount of state revenue available but also depend on the willingness of elected officials to raise taxes.

\section{From Equity to Adequacy: The Evolution of Court- Mandated Finance Reform}

By the late 1960 s, fiscal inequities caused by uneven distributions of the local tax base and insufficient state equalization programs led education reformers to challenge state school finance systems in the courts. The reformers based their claims on the equal protection clauses in both the federal and state constitutions that were interpreted by the courts to impose a legal responsibility on the states "to ensure that equal tax efforts yielded equal resources" (Olson $2005,11)$. The success of this strategy in a California case, Serrano v. Priest (1971), was quickly overturned when the United States Supreme Court ruled in San Antonio Independent Scbool District u. Rodriguez (1973) that education "fall[s] outside a limited category of rights recognized...as guaranteed by the [federal] Constitution" (Powell 1973, 9). Since this landmark decision, forty-five of the fifty states have been embroiled in school finance litigation, fueled by state constitutional clauses guaranteeing either equal protection or adequate education (ACCESS, National Historical Background, n.d.). Sixteen states are presently engaged in the litigation process (Olson 2005).

Over the course of this long and complicated history of litigation, two concepts have been central: equity and adequacy. While both equity and adequacy appear to be relatively straightforward concepts, they are, in fact, extremely complex and hard to define in the context of school finance. 


\section{Equity as the Basis for}

\section{State Reforms}

The first attempts at school finance reform, initiated in the 1970s and early 1980s, focused on the concept of "equity" in school finance. In a general sense, the term "equity" means fundamental fairness; in the context of school financing, equity implies that all children are entitled to a sound education whether they live in a property-rich or property-poor district. Education reform efforts based on the concept of equity aim either to create an equal distribution of the educational inputs (e.g., labor, equipment, and capital) or educational outputs and outcomes (e.g., graduation rates, student performance, and lifetime earnings). Deciding precisely how to define equity necessarily involves difficult "value judgments about how to determine fairness in financing of K-12 education" (Berne and Stiefel 1999, 7-26). Thus, as individual states choose to define equity differently, they also are likely to choose different distributions of educational resources.

Assessing whether various equity approaches actually achieve their intended goals requires an understanding of the underlying principles of school finance reform. Traditionally, states have tried to integrate equity into their school financing systems in one of three ways:

a) Fiscal neutrality refers to the traditional school finance view that resources should not vary with local fiscal capacity (namely property wealth per pupil) (Odden and Picus 2000). This principle is derived from the broader American belief in equal opportunity for all students, which holds that success should not be contingent on factors outside a child's control such as geographic location, ethnicity, or gender.. Specifically, this idea means that poor districts should not be required to impose extremely high tax rates on themselves in order to furnish their students with the same level of educational resources as is provided to students in wealthy districts. Proponents of reform used this idea as the basis of the earliest legal challenges in the school finance teform movement. b) Hotizontal equity specifies that students with like characteristics should be treated alike. This principle is best applied when comparing resource distributions across equally situated subgroups of students, such as at-risk or elementary school students. However, this view generally is not useful given the heterogeneity of most school-age populations. For this reason, horizontal equity is most often used to justify the creation or separation of funding streams specifically meant for compensatory or other purposes from streams meant for all students (Berne and Stiefel 1999, $7-26)$.

c) Vertical equity specifies that differently situated children should be treated differently. Thus, the goal is not that educational resources provided per pupil will be equally distributed but rather that the resources are proportionally distributed according to differences in student needs. ${ }^{1}$ This principle inherently links input equity to output equity because it recognizes that different types of children may be more or less costly to educate and adjusts inputs and expenditures accordingly. For example, consider the fact that poor students commonly are more expensive to educate than are students from wealthy families. In order to achieve vertical equity, it is likely that more money must be spent to educate poor students than wealthy students.

Given these various interpretations of equity, it is not surprising that school finance structures are markedly different from state to state. For example, one state, following vertical equity ptinciples, could give additional funding to school districts with a large proportion of high-needs students and less money to other districts, provoking lawsuits and charges of unfairness from the parents in the less-funded districts. Alternatively, another state may see just such an arrangement upheld in court on the theory that unequal school funding might be deemed equitable on the basis of fiscal neutrality "if the difference arises from the choice of local communities to adopt higher or lower school taxes" (emphasis added) (Terman and Behrman 1997, 4-23). Thus, although parents and reformers 
initially prevailed in overturning state financing systems based on equity claims, "by the mid-1980s, defendants [states] were winning most of these cases, primatily because the courts had great difficulty in devising solutions for the problem of funding inequities" (Rebell 2001, 2).

\section{The Shift from Equity to Adequacy in}

\section{Education Reform Efforts}

Beginning in the late $1980 \mathrm{~s}$, the legal strategy for achieving school finance reform shifted from equity to adequacy. Unlike equity claims, which focus on the relative differences between groups, the adequacy framework focuses on whether or not the provision of an absolute level of resources ${ }^{2}$ is sufficient to meet defined levels of achievement (Berne and Stiefel 1999, 7-26). Therefore, an adequate school finance system would provide the resources necessary for students to attain a specified level of achievement. In general, adequacy-based lawsuits have resulted in more legal victories for advocates of reform, in part because this approach often exposes the shortfall between what students currently receive and what they need to succeed at high levels (Minorini and Sugarman 1999, 175-207).

Despite its relative success as a legal strategy, integrating adequacy into a school finance system remains a difficult task due in part to the lack of solid research providing definitive answers to the following questions:

1) What constitutes an "adequate" level of school quality or educational outcomes; and

2) How much funding is necessary to meet these objectives (Figlio 2004)?

These two fundamental questions have led nearly thirty state governments to conduct "costing-out" studies since 1991 (ACCESS 2003a). These studies allow states to systematically determine the true cost of providing every child access to the educational services necessary to meet the relevant state education standards and thus provide an "adequate" education (ACCESS 2003b).

There are many costing-out methodologies, each using a different standard to determine an adequate expenditure level. The four most commonly used methodologies are:

\section{1) The "successful schools" approach} identifies districts that are successful in teaching their students to proficiency standards and sets the adequacy level at the weighted average of the per-pupil expenditures of these districts;

\section{2) The "professional judgment" approach} relies on the knowledge of educational experts by asking them to identify effective educational strategies for students of different ages and ability levels and then to attach a price to each component needed to implement these strategies;

\section{3) The "evidence-based" approach relies on} research to identify individual strategies or comprehensive school designs that might produce the desired goals and then calculates how much it would cost to implement those strategies in schools; and

4) The "cost function" method uses statistical models to study the relationship between a desired level of student performance and associated levels of spending for students and districts with varying characteristics (Olson 2005, 12).

In addition to standards used by states in costingout studies, the federal government has contributed to the shift toward adequacy-based school financing through mandated standards in its recent accountability legislation. Previously, graduation rates or measures of "citizenship", such as voting ability or delinquency, served as the benchmarks for student performance. Under the No Child Left Behind Act, the federal government sets its own definition of an adequate education and requires states to implement achievement standards in accordance with those principles. The imposition of federal standards has also revealed that, in order to bring about these ambitious educational outcomes, states require a substantial amount of money from the federal government although no one is quite sure how to develop funding formulas that will reliably or accurately distribute educational resources. ${ }^{3}$ 


\section{Compatibility of equity and adequacy}

Understanding the concepts of adequacy and equity is further complicated by the fact that the distinction between the two is often blurred. Although equity is traditionally defined as input-based (i.e., resources) and adequacy as output-based or outcomebased (i.e., educational achievement standards), it is certainly reasonable to focus on the adequacy of inputs or the equity of outputs (Figlio 2004). For instance, the concept of adequacy does not set a ceiling on the provision of resources nor does it prohibit communities from providing their children with more than the minimum level of resources necessary to meet state standard achievement levels (Minorini and Sugarman 1999, 175-207). While most adequacy supporters see this development as an acceptable one, it also highlights the glaring inequities that might result if districts with higher fiscal capacity can purchase educational advantages well worth having (Minorini and Sugarman 1999, 175-207).

\section{State of The State: Why NeW}

\section{York's School Finance}

\section{Structure Needs to Be Fixed}

The concepts of equity and adequacy have had tremendous influence in framing school finance debates across the country, as illustrated by the situation in New York State. Statewide, New York spends approximately $\$ 30$ billion annually (Hoff 2005,29 ) to educate the nearly three million students in its 677 school districts (NYS-DOB 2005). More than a third of these students reside in New York City, which is by far the state's largest district. In 2004, the city's public education budget totaled $\$ 12.7$ billion with approximately 45 percent of this money coming from the state (IBO 2004, 1). Despite the enormity of these figures, New York City is actually considered a "poor" school district. As a result, many education advocates argue that the state's poorer school districts, including New York City, have been shortchanged of the resources necessary to ensure that their students receive the "sound, basic education" guaranteed by the state's constitution.

Research seems to support their claims. A 2004 report by the Education Trust found that New York's highest poverty districts received $\$ 2,040$ less per pupil than its lowest poverty districts, the largest education funding gap in the country (Carey 2004). Fiscal inequities have had discernible effects on the resources provided to students in high-poverty areas as described in a 2002 report by the Government Accountability Office $(G A O)^{4}$ documenting differences in per-pupil expenditures and other factors related to student achievement actoss six metropolitan areas. That study also found that suburban New York City schools not only outspent inner city schools but that the differences between inner city and suburban school spending were substantially enlarged when the analysis included weights to adjust for student needs (GAO 2002, 14). ${ }^{5}$ The study also found that New York City schools had significantly higher enrollment rates than the national average as well as more first-year (and hence, less experienced) teachers compared to their suburban counterparts (GAO 2002). Finally, the selected inner city schools also had fewer library books per 100 students and were less likely to have a computer lab than the suburban schools (GAO 2002).

Although research about how resources affect outcomes remains inconclusive, this inadequate and inequitable distribution of basic educational resources seems to have had a negative effect on student achievement in New York's high-needs districts. For instance, average student achievement scores in New York City's schools were found to be lower than both the state average and the neighboring suburbs' scores (GAO 2002). Additionally, a 2004 report ranked New York State $43^{\text {rd }}$ in the country for overall high school graduation rates and highlighted New York City as having one of the worst graduation rates (38 percent) among America's large cities (Wheaton 2004).

While these statistics underscore the adverse effects of budgetary shortfalls on New York City's public schools, other high-needs districts ${ }^{6}$ throughout the state, including the Big 4 (Yonkers, Syracuse, Buffalo, and Rochester) and small rural communities, are facing similar issues. Given these circumstances, one might expect the state to mitigate such disparate conditions by providing additional funding to these 
districts. However, New York failed to ameliorate these financing problems, resulting in years of litigation that could finally serve as the impetus for redesigning the state's school finance system.

\section{Judicial Intervention: A Historical}

\section{Overview of New York's}

\section{School Finance Litigation}

In its first school finance case, Levittown v. Nyquist (1982), the Court of Appeals, New York's highest state court, considered a case brought by a group of property-poor Long Island school districts, joined by New York City and the other four large urban districts in the state, that challenged the state's education finance system on equity grounds. Despite its acknowledgement of substantial school funding inequities across the state, the court declared that the state's Constitution did not explicitly require school spending to be horizontally equitable actoss districts. However, the judges did note that the Constitution entitled students to a "sound, basic education" (NYSASCSD 2004).

This language eventually formed the basis of the Campaign for Fiscal Equity's (CFE) 1995 lawsuit charging that the state had failed in its obligation to provide a sound, basic education for New York City's schoolchildren. A central component of CFE's argument was that the state's method of financing education deprived New York City's students of many essentials that they needed to meet the state's own education standards. ${ }^{7}$ The Court of Appeals responded by amending its previous decision, indicating that if CFE could present ample evidence that thousands of children were denied an adequate education the court would mandate reform (LII 1995).

After eight years of litigation, the Court of Appeals issued its final ruling in favor of CFE in June 2003, declaring, "the share of state aid going to City schools does not bear a perceptible relationship to the needs of City students" (Kaye 2003, 50). As such, the Court of Appeals gave the state until July 30, 2004, to devise a plan that would comply with its order. ${ }^{8}$ When the state did not meet the imposed deadline, Supreme Court Justice Leland DeGrasse appointed a panel of judicial referees to address the state's non-compliance and develop a plan that would resolve the funding inadequacies.

Following six weeks of extensive oral arguments from both CFE and the State of New York, the panel issued its final recommendations on November 30, 2004 , in which the referees concluded that New York City's public schools would need an additional $\$ 5.63$ billion each year in operating aid to provide its students with the basic resources to which they are entitled under the state constitution (Feerick et al. 2004). After hearing oral arguments in mid-January from both the plaintiff and the defendant regarding the panel's report and recommendations, Justice DeGrasse issued a statement in support of the panel's findings, thus obliging the legislature to enact and implement the necessary changes (CBC 2004). However, political wrangling over funding of New York City schools may prevent this decision from having any immediate effect on students. In mid-February, Governor Pataki announced his plan to appeal the decision, which is likely to prolong the process for another year or more (Cooper, The Nen York Times, February 16, 2005).

\section{Issues TO CONSIDER:}

\section{The Future of New York}

\section{StATE's School FinaNCE}

\section{SYSTEM}

Although this case has focused on remedying funding inequities for New York City's schools specifically, this ruling could have significant implications for the state's entire school finance system due to the central role that state aid plays in the provision of school resources. As such, it is important to understand the problems embedded in New York's existing school finance structure as well as potential changes that would ensure consideration of adequacy and equity in future redesign efforts. ${ }^{9}$

Perhaps the most obvious reason for the system's current dysfunction is the role of politics in school financing. The current school financing system is largely the product of political maneuvering by the state's legislative leaders, resulting in the distribution 
of education funds through many convoluted, restrictive formulas that do not accurately reflect the costs of providing students with a "sound, basic education." "The politicization of school financing not only limits the ability of financing formulas to meet their stated objectives but also keeps the formulas from incorporating true measures of efficiency, stability, and accountability.

This dysfunction is best illustrated by a telling example: despite the state's collection of 40 or so formulas and grants purporting to deliver aid under a percentage-equalizing system (CFE 2000), New York City received a fixed percentage of state aid increases (38.36 percent) every year from 1990 to 2000 as part of a long-standing political deal between the state's three political leaders (CFE 2000). Given the fluctuating needs of New York City's largely "highneeds" student population, the state might be expected to be more flexible in awarding these allocations rather than consistently providing a fixed percentage of aid. While the percentage-equalizing system was suspended in the 2000-01 school year, ${ }^{11}$ the state continues to utilize a large number of complex and burdensome formulas to determine funding levels, making it extraordinarily difficult for both policymakers and the general public to fully understand the aid distribution process. Even the Court of Appeals' final ruling suggested that this process is symptomatic of the underlying inadequacies plaguing the state's existing school financing scheme, describing it as "needlessly complex, malleable, and not designed to align funding with need" (CFE 2004, 5).

In addition to a financing scheme that elevates political concerns above educational achievement, New York's school finance system fails to effectively address the principle of vertical equity. Thus, even though school spending in New York has tisen by more than $\$ 5$ billion over the past ten years (NYSGPO 2005), state aid increases have not necessarily targeted districts serving a higher proportion of students who are petforming below standards. ${ }^{12}$ Additionally, while most of the formulas provide more aid to poorer districts (known as 'equalization aid'), certain quirks have limited the effectiveness of equalization efforts (McCall, 2000). For instance, some formulas include "save harmless" provisions which protect schools from reductions in aid regardless of lower student enrollment, lower expenditures, or higher wealth (McCall 1995). The implementation of a "needs" index would correct these quirks by adjusting aid to reflect varying concentrations of poverty, disability levels, number of English language learners, and school sizes across the state and would likely result in more equitable funding to high-needs school districts (CFE 2004).

The present finance system is also flawed because it relies on formulas that assume that the cost of services is the same in every region of the state. As a result, the state's aid formulas do not account for differences in regional costs, thereby under-funding districts in regions in which costs are particularly high (CFE 2000). However, concerns about vertical equity must also be offset by a consideration of the economies of scale that result from funding schools in a multischool urban area such as New York City (CFE 2000). As such, policymakers should adopt a geographic costof-education index so that funding allocations reflect the real costs incurred by different districts.

In addition to differences in regional costs, policymakers must be aware of how the elasticities of different tax revenue sources affect the distribution of the state and local cost burden. For example, New York City's reliance on a diversified tax base (particularly the income tax) makes it more susceptible to cyclical changes in the economy than local districts that rely heavily on the property tax, which is relatively stable (CFE 2000). Additionally, urban areas incur substantial costs in providing public services to lowincome populations (e.g.; Medicaid and public assistance) and take on debt to meet these costs so these districts face significant difficulties in adequately funding their schools.

To account for these variations in local fiscal responsibilities, future efforts to redesign the state's operating aid system could include the institution of mandatory local and state share formulas. Incorporating a mandatory local share formula into the funding system would require each locality to pay a specific portion of educational expenses based on the district's "ability to pay" (and, hence, reflect the principle of vertical equity), but would not limit a local area from making a greater contribution than the minimum necessary to meet a given adequacy standard (CFE 2004). A mandatory state share would reduce 
inequities because the state would be required to pay the difference between the mandatory minimum amount of resources provided to the districts and the amount generated by the local share and federal aid combined (CFE 2004).

Another weakness of New York's school financing structure is its failure to provide school districts with predictable levels of funding that remain constant from year to year. Much of this lack of consistency can be attributed to the infighting among the state's political leadership which often paralyzes the budget process and leaves school districts unsure of the amount of aid to expect from year to year (Metzler 2003). This uncertainty combined with the inadequacy of funds makes it difficult for many communities to meet the required level of educational achievement and to plan for funding shortfalls. ${ }^{13}$

These concerns are further compounded by problems with the formulas themselves. The current formulas rely on a percentage of a per-pupil amount set prior to the implementation of the Regents' Learning Standards (Little 2004), ${ }^{14}$ suggesting that the formulas do not measure the true cost of providing adequate resources for students to meet state accountability standards. Additionally, because recent increases in state education spending have generally come in the form of categorical aid rather than unrestricted aid, many poorer districts are forced to spend more on certain categories (i.e., instructional materials) which are central to school operations but do not appear to have a direct effect on student performance.

\section{Conclusion}

In spite of these daunting realities, future efforts to reform New York's school finance system should not be abandoned. To promote stability and long-range planning, future proposals should require the state to adopt a multi-year funding plan which sets forth in advance the amount each district will receive for a specified period of time and is subject to inflationary increases or adjustments for unforeseen events (CFE 2004).

Any future reform proposals must establish a comprehensive foundation amount for all districts based on a thorough review of the multiple "costing- out studies" undertaken to comply with the Court of Appeals' remedial order. ${ }^{15}$ Further, the state should make a commitment to revisit and re-evaluate the school finance system through periodic follow-up studies in order to ensure that the established system is continually evolving to meet new standards in an equitable manner. Such reviews will ensure that solid evidence-based research takes precedence in deciding "adequate" district aid amounts rather than legislative manipulation, both now and in the future. At the same time, successful reform proposals will also need to take into account the realities of New York's political environment.

This discussion of current deficiencies in New York's system of school finance underscores the need for reform that will effectively address the principles of equity and adequacy while also providing schools and school districts with stable and predictable funds so that they can effectively provide their students with essential educational resources. Regardless of the challenging nature of this task, these recommendations should be pursued to ensure that New York's students are not denied their constitutional right to a sound, basic education over the long term. While money is surely not all that matters, redesigning state school financing structures to provide adequate resources in a more equitable fashion could go a long way toward accomplishing these goals.

\section{Notes}

${ }^{1}$ While some educational resources, such as salary levels and energy costs, are relatively easy to accommodate in vertical equity calculations, the amount of resources to distribute to each different category of students is much more difficult to determine because there is little evidence on how educational resources are directly related to student achievement (Berne and Stiefel 1999, 7-26).

${ }^{2}$ These resources include teachers, facilities, curriculum standards, and other resources needed to produce certain outcomes such as attaining proficiency on a state achievement test. 
${ }^{3}$ This observation alludes to the argument made by many states that the No Child Left Behind Act is severely under-funded and requires significantly more federal resources than those actually provided to achieve the desired levels of proficiency stated in the bill. For more information, see Wasbington Post article by Michael Dobbs (2/19/04) "More States are Fighting 'No Child Left Behind' Law" or Education Week article by David J. Hoff (2/4/04) "Debate Grows on 'True Costs of School Law".

${ }^{4}$ On July 7, 2004, the General Accounting Office changed its name to the Government Accountability Office, per the GAO Human Capital Reform Act of 2004, Pub. L. 108-271, 118 Stat. 811 (2004).

${ }^{5}$ See Figures 2 and 4 in GAO's December 2002 report "School Finance: Per-pupil Spending Differences between Selected Inner City and Suburban Schools Varied by Metropolitan Area" (GAO-03-234), p.10 and p.15 respectively.

6 "High-needs districts" typically refers to those districts with large concentrations of costly-to-educate students, such as students with disabilities, limited English proficiency, or high-poverty backgrounds. These districts also typically have low to average property wealth per pupil.

${ }^{7}$ These educational essentials include qualified teachers; clean, spacious, and safe school buildings; access to current education tools and curricula (including textbooks, computers, and libraries); and small class sizes.

${ }^{8}$ The Court outlined a three-part remedy to be carried out by the July 30, 2004 deadline: "1) the state must ascertain the 'actual cost of providing a sound basic education' in New York City, 2) the state must reform the funding system to ensure that 'every school in New York City would have the resources necessary for providing the opportunity for a sound basic education,' and 3) the state must put in place a system of accountability that will ensure that the reforms actually provide this opportunity." (Campaign For Fiscal Equity, http://www.cfequity.org/CrtofAppeals2003.PDF).
${ }^{9}$ Changes discussed here reflect CFE's plan to reform the state's school finance system, which has been endorsed by several organizations and experts in New York. For more information, see An Adequate Foundation for All: Reforming Nen York State's System for Providing Operating Aid to Local School Districts (CFE 2004).

${ }^{10}$ This article uses the Court of Appeals' definition of a "sound, basic education" which states that all students should have access to "a meaningful high school education, one which prepares them to function productively as civic participants." Other elements necessary to achieving this goal include high-quality teaching, small class sizes, and adequate instrumentalities of learning, such as classroom supplies, textbooks, libraries and computers.

${ }^{11}$ Since this time, districts have simply received a uniform percentage increase over the previous year's allotment, according to the New York "Finance Snapshot" published by Education Week on January 6, 2005 (http://www.edweek.org/ew/articles/2005/01/ 06/17statesums-ny.h24.html).

${ }^{12} \mathrm{See}$ A \$3.4 Billion Opportunity Missed: Despite Four Years of Large Increases State Scbool Aid Formulas Still Don't Provide Equitable, Predictable, or Efficient Funding (McCall 2000, 19).

${ }^{13}$ For an interesting discussion of the interactions of state aid in interjurisdictional funding inequities, see "Prospects for Achieving Equity or Adequacy in Education: The Limits of State Aid in General Equilibrium" by Thomas Nechbya (Yinger 2004).

${ }^{14}$ In 1996, the New York State Board of Regents adopted learning standards in seven subject areas that all students have to meet in order to graduate from high school.

${ }^{15}$ Three different costing-out studies were conducted to determine the cost of providing a sound, basic education (SBE) in New York. The study conducted by AIR/MAP on behalf of CFE used the professional judgment approach; the studies by the Standard \& Poor's on behalf of the Zarb Commission (the state's education finance reform committee) and by the Boatd of Regents used the successful schools approach. Cost 
estimates for providing an SBE varied tremendously because of different assumptions made by the resea rchers but range from an additional $\$ 2.5$ billion to $\$ 7.2$ billion annually.

\section{REFERENCES}

Advocacy Children's Center for Educational Success with Standards (ACCESS). National Historical Background. http://www.schoolfunding.info/ litigation.

Advocacy Children's Center for Educational Success with Standards (ACCESS). 2003a. Ensuring all children the opportunity for an adequate education: Standards-basedreform. http://www.schoolfunding. info/policy/CostingOut/overview.php3.

Advocacy Children's Center for Educational Success with Standards (ACCESS). 2003b, July. Ensuring all children the opportunity for an adequate education: A Costing-out primer. http://www. schoolfunding. info/resource_center/research/CostingOut Primer.pdf.

Albany Times Union. 2005. Wrong call. Albany Times Union, February 18.

Augenblick, John, John Myers, and Amy Anderson. 1997. Equity and adequacy in school funding. Future of Children: "Financing Schools" 7(3): 63-79. http:// www.futureofchildren.org/usr_doc/ vol7no3ART5.pdf.

Berne, Robert, and Leanna Stiefel. 1999. Concepts of School Finance Equity: 1970 to the Present. In Equity and adequacy in education finance: Issues and perspectives. Ed. Helen Ladd, Rosemary Chalk and Janet Hansen. Washington, DC: National Research Council, National Academy Press.

Campaign for Fiscal Equity (CFE). 2000. In evidence: Policy reports from the trial (CFE v. New. York), Reforming New York's flawed state school finance system. http://www.cfequity.org/funding.pdf.

Campaign for Fiscal Equity (CFE). May 11, 2004. Ensuring educational opportunity for all, Part I. An adequate education for all: Reforming New York State's system for providing operating aid to local school districts. In Report of the Sound Basic Education Task Force. http://www.cfequity.org/ operatingaidproposalfinal.pdf.

Carey, Kevin. 2004. The funding gap. Washington D.C.: The Education Trust. http://www2.edtrust.org/ NR/rdonlyres/30B3C1B3-3DA6-4809-AFB92DAACF11CF88/0/funding2004.pdf

Citizens Budget Commission (CBC). 2004. Can New York get an $\mathrm{A}$ in school finance reform? http:// www.cbeny.org/CBC_School_Finance_Reform_1104.pdf.

Clearinghouse on Educational Policy and Management (CEPM). 2001. New attention to outcomes and adequacy. http://eric.uoregon.edu/trends_issues/ finance/04.html.

Feetick et al. 2004. Report and Recommendatios of the Judicial Referees. New York. http://www.cfequity.org/ compliance/RefereesFinalReport11.30.04.pdf.

Figlio, David. 2004. Funding and accountability: Some conceptual and technical issues in state aid reform. In Helping children left behind: State Aid and the pursuit of educational equity. Edited by John Yinger. Cambridge: MIT Press.

Guthrie, James W., and Richard Rothstein. 1999. Enabling "adequacy" to achieve reality: Translating adequacy into state school finance distribution arrangements. In Equity and adequacy in education finance: Issues and perspectives. Ed. Helen Ladd, Rosemary Chalk and Janet Hansen. Washington, DC: National Research Council, National Academy Press.

Hoff, David. 2005. The bottom line. Education Week 24(17): $28-36$.

Independent Budget Office (IBO). 2004. Settling school finance suit may cost city millions. Inside the Budget. Number 130. http://www.ibo.nyc.ny.us/newsfax/ Insidethebudget130.pdf.

Kaye, Judith et al. 2003. Campaign for Fiscal Equity v. the State of New York, New York Court of Appeals. http://www.nysut.org/research/bulletins/ 030626cfedecision.pdf. 
Legal Information Institute Bulletin (LII). June 13, 1995. Campaign for Fiscal Equity, Inc. 1. State, 86 N.Y.2d 307. New York. http://www.law.cornell.edu/ nyctap/comments/i95_0156.htm.

Little, David. 2004. Testimony of New York State School Board Association before the NYS Joint Legislative Fiscal Committee Departmental Budget Hearing, Elementary \& Secondary Education. Albany, NY. http://www.nyssba.org/adnews/ nyssbanews/news020904.htm.

McCall, Carl. 2000. A $\$ 3.4$ billion opportunity missed: Despite four years of large increases state school aid formulas still don't provide equitable, predictable, or efficient funding. Office of the New York State Comptrollet. (NYSC). http://www.osc.state.ny.us/reports/schools/2000/ 34bill.pdf.

McCall, Carl. 1995. School finance reform: A discussion paper. Office of the New York State Comptroller (NYSC). http://www.osc.state.ny.us/reports/schools/1995/ 10-95.htm.

Metzler, James. 2003. Inequitable equilibrium: School finance in the United States. Indiana Law Review 36. http://www.schoolfunding.info/resource_ center/research/Metzler.pdf.

Minorini, Paul A, and Stephen D. Sugarman. 1999 Educational adequacy and the courts: The promise and problems of moving to a new paradigm. In Equity and adequacy in education finance: Issues and perspectives. Ed. Helen Ladd, Rosemary Chalk and Janet Hansen. Washington, DC: National Research Council, National Academy Press.

New York State Association of Small City School Districts, Inc. (NYSASCSD). 2004 Brief for Amicus Curiae. Albany: NYSASCSD.

http://www.cfequity.org/SCSDcabrief.PDF.

New York State Division of Budget (NYSDOB). 2005. School Aid Budgets. Albany: NYSDOB. http://www.budget.state.ny.us/.

New York State Governor's Press Office (NYSGPO). 2005. Governor Pataki's 2005 budget address. January 18. http://www.budget.state.ny.us/ localities/schoolaid/schoolaid.html.
Odden, Alan R. 1992. Retbinking school finance. San Francisco: Jossey-Bass Inc.

Odden, Alan R., and Lawrence O. Picus. 1992. School finance. A policy perspective: New York: McGraw-Hill, Inc.

Olson, Lynn. 2005. Financial evolution. Education Week 24(17): 8-13

Powell, J. 1973. San Antonio Independent School District Rodriguez, U.S. Supreme Court Decision. http:// www2.law.cornell.edu/.

Rebell, Michael. 2001. Education, adequacy, and democracy in the courts. From forthcoming publication by the National Academy of Sciences and National Research Council. http://www.school

funding.info/resource_center/research/ EDUADEQ.PDF.

Terman, Donna L., and Richard E. Behrman. 1997. Financing Schools: Analysis and Recommendations. Future of Cbildren "Financing Schools" 7(3): 4-23. http: //www.futureofchildren.org/usr_doc/ vol7no3ART1.pdf.

U.S. General Accounting Office (GAO). 2002. Per-pupil spending differences between selected inner city and suburban schools varied by metropolitan area. Washington D.C.: GAO.

Wheaton, Patricia. 2004. Low graduation rate for NYC, minority students. Insideschools.org, March 2.

http://www.insideschools.org/nv/NV_ minority_grad_mar04.php.

Yinger, John editor. 2004. Helping children left behind: State aid and the pursuit of educational equity. Cambridge: MTT Press. 
